\title{
Energy decisions within an applied ethics framework: an analysis of five recent controversies
}

\author{
Jacob Bethem', Giovanni Frigo ${ }^{2}$, Saurabh Biswas ${ }^{3}$, C. Tyler DesRoches ${ }^{3,4,5^{*}}$ and Martin Pasqualetti ${ }^{6}$
}

\begin{abstract}
Everywhere in the world, and in every period of human history, it has been common for energy decisions to be made in an ethically haphazard manner. With growing population pressure and increasing demand for energy, this approach is no longer viable. We believe that decision makers must include ethical considerations in energy decisions more routinely and systematically. To this end, we propose an applied ethics framework that accommodates principles from three classical ethical theories - virtue ethics, deontology, consequentialism, and two Native American ethics (Lakota and Navajo) - all considered from the perspectives of the impacted communities. We illustrate this framework by evaluating five recent energy decisions: the Dakota Access Pipeline, the Navajo Nation's possible transition from coal to solar, hydraulic fracturing in Pennsylvania, uranium mining in Virginia, and the construction of the Xiaolangdi Dam in China. An applied ethics framework is preferable to existing ethical analyses because it can serve to sharpen arguments for (un)ethical decisions and action. Rather than treat ethical reasoning as a matter of opinion, we argue that applying ethical principles in a universal and standardized way adds rigor to energy sector decisions by presenting a position available for objective scrutiny. Because our framework identifies which aspects of a targeted action (if any) must adjust to improve ethical merit, it can serve as a practical tool for improving decision-making as we enter a new era of energy transitions.
\end{abstract}

Keywords: Energy, Energy transitions, Applied energy ethics, Philosophy

\section{Introduction}

The majority of global greenhouse gas emissions arise from energy conversion and consumption [1]. Transitioning towards carbon-free and affordable energy resources will be among the most important decisions we will make to protect human habitability on Earth [2]. Energy decisions have many ethical dimensions, including significant effects for members of present and future generations. In some cases, energy decisions can determine who lives and dies, cause irreversible changes to the planet, or lock societies into harmful infrastructures or socio-economic arrangements that perpetuate

\footnotetext{
* Correspondence: tyler.desroches@asu.edu

${ }^{3}$ School of Sustainability, Arizona State University, Tempe, AZ, USA

${ }^{4}$ School of Historical, Philosophical and Religious Studies, Arizona State University, Tempe, AZ, USA

Full list of author information is available at the end of the article
}

for centuries. Therefore, these decisions should not be made without regard to ethics. In response to recognizing the ethical dimensions of energy decisions, a growing number of energy scientists and scholars have called for greater attention to ethics in energy research [3, 4], ethics training for energy workers, and a form of "Hippocratic Oaths" for energy decision makers to "do no harm" [5]. While some researchers have responded to these calls with a set of "energy justice" principles [6], we propose principles of energy ethics to serve as a practical guide for energy decision-making. ${ }^{1}$ This

\footnotetext{
${ }^{1}$ While justice, ethics, and law are sometimes conflated, these concepts are separate and distinct. For example, what is just need not be ethical and vice versa. We do not have the space here for a complete analysis of this conceptual issue, but interested readers can find further details online [7].
}

(C) The Author(s). 2020 Open Access This article is licensed under a Creative Commons Attribution 4.0 International License, which permits use, sharing, adaptation, distribution and reproduction in any medium or format, as long as you give appropriate credit to the original author(s) and the source, provide a link to the Creative Commons licence, and indicate if changes were made. The images or other third party material in this article are included in the article's Creative Commons licence, unless indicated otherwise in a credit line to the material. If material is not included in the article's Creative Commons licence and your intended use is not permitted by statutory regulation or exceeds the permitted use, you will need to obtain permission directly from the copyright holder. To view a copy of this licence, visit http://creativecommons.org/licenses/by/4.0/ The Creative Commons Public Domain Dedication waiver (http://creativecommons.org/publicdomain/zero/1.0/) applies to the data made available in this article, unless otherwise stated in a credit line to the data. 
Table 1 Applied ethics framework

Ethical perspective
Virtue Ethics
Aristotle's "Golden Mean" defines virtue as a moderate intermediate between extreme vices
of excess and deficient action. An individual's repeated actions are habits which constitute
one's character [9]. Virtuous habits made of moderate actions demonstrate human
flourishing, excellence, or role model behavior. Vicious habits made of excessive or deficient
actions hinder flourishing. Virtuous habits are ethical, and vicious habits are unethical.
Deontology
Kantian deontology includes three tests: intentions, universalizability, and respect. Kant
describes ethics as obligations (duties) that all rational beings could discover through reason
[10]. Kant focuses on the intentions that give reason to performing the action. Good
intentions produce ethical actions, while bad intentions lead to unethical actions. Kantian
ethics is absolute and applies to everyone equally; therefore, an action is ethical if it can be
universally obligated and unethical if it would be self-defeating to obligate the action. Au-
tonomy plays an important role since it allows the expression of reason and is the source of
human dignity. Respect is then defined as honoring the autonomy of others by refusing to
use them involuntarily for one's own benefit without consent. Actions that show others re-
spect are ethical, while disrespectful actions are unethical.

\section{Consequentialism}

Consequence-based ethics, such as utilitarianism, employ a maximizing rule to seek "the greatest good for the greatest number" of people or "the most good for the most people," called the "Greatest Happiness Principle" [11, 12]. Consequentialists typically conduct a "calculus" weighing positive and negative consequences for all stakeholders, similar to a cost-benefit analysis. They often treat the action with the highest "net good" (the total of the positive consequences reduced by the number of negatives) as the only ethical option, while other options are treated as unethical.

\section{Lakota Sioux}

Representing one of many Sioux tribes, Lakota ethics reflect traditional values of bravery, generosity, fortitude, and wisdom and perpetuating cycles, described as "the hoop" and "circles" of life. "Virtuous circles explicate increasingly positive human behavior in social systems, whereas vicious circles explain pathological negative spirals," such as poverty, depression, alcoholism, violence, or greed [13-16].

\section{Navajo}

The Navajo people have terms for good (hózhó) and evil (hóchó). While Navajos are generally taught that "you can do what you want" and typically describes ethics as "relative to situation and to consequences rather than absolute," they still condemn "actions which would make life in general impossible," including rape, theft, molestation, jealous arguments, wishing ill of others, ridicule, adultery, killing, and lying. Navajos oppose "monsters" akin to vices, such as "selfishness, greediness, envy, hate, and jealousy." Navajos see using someone else involuntarily for one's own gain as a form of witchcraft, requiring restitution (nalyeeh) or punishable by death $[17,18]$.

\section{Associated ethical principle}

Avoid excessive or deficient action

Avoid actions that hinder human flourishing, diminish character

\section{Avoid self-defeating actions}

Do not use people involuntarily for one's own gain

Avoid actions which produce more harms than benefits

Act with bravery, generosity, fortitude, and wisdom

Act mindful that actions perpetuate increasing positivity or pathological negativity

Respect all as relatives, respect the land

Do not steal, argue jealously, wish ill, ridicule, commit adultery, kill, or lie

Honor duties to one's kin group

Seek restitution

Respect all as relatives, respect the land alternative approach is intended to complement, not supplant, other normative approaches to energy ethics [8].

This short communication introduces a framework for making ethical energy decisions in real-world scenarios, illustrating how policy makers and others can use it. The proposed framework (Table 1) is designed to be flexible and accommodate principles from multiple ethical perspectives (virtue ethics, deontology, consequentialism, Lakota Sioux, and Navajo) simultaneously. Each principle is described in Table 1 . To be clear from the outset, we remain neutral on the correctness or truth of any particular ethical theory or principle. Instead, our main goal is pragmatic. The framework is intended to contribute meaningfully to the growing and vibrant field of energy ethics by employing a plurality of wellestablished and philosophically defensible ethical principles that illuminate our obligations to others, providing a set of high-level guidelines for making practical decisions. $^{2}$

\section{Methods}

Next, we describe example cases in Table 2. We have selected five recent and high-profile energy decisions as examples: the Dakota Access Pipeline [19], the Navajo Nation's transition away from coal and possibly to solar [20], hydraulic fracturing in Washington County, PA [21], uranium mining in Virginia [22], and the construction of the Xiaolangdi Dam in Jiyuan, Henan Province, China [23].

${ }^{2}$ We reasonably assume that, other things being equal, energy decision makers wish to make ethical decisions. 
Table 2 Energy ethics cases

\begin{abstract}
1. The Dakota Access Pipeline provides potentially safer transport than by train but risks contaminating water for communities across the Great Plains, including a Lakota Sioux reservation. Should the pipeline have been built?

2. The Navajo Generating Station coal plant and Kayenta Mine in Arizona have become uneconomic to operate but have provided jobs and revenues upon which the Navajo and Hopi communities have critically depended for decades. Should the plant and mine have been closed?

3. Fracking for natural gas has revitalized Washington County, PA, which has struggled since steel mills were closed decades ago but threatens the county's drinking water. Should fracking continue?

4. A moratorium against uranium mining in Virginia leaves one of the country's potentially largest sources of energy untapped due to fears of radiation poisoning and dwindling nuclear energy market. Should the ban be lifted?

5. Flood control, irrigation, and abundant clean energy can all be addressed through a megadam such as the Xiaolangdi Dam along the Yellow River in the Henan Province of China, but it caused 200,000 people to be displaced and tremendous social and environmental damage. Should the dam have been built?
\end{abstract}

Each of the foregoing cases was controversial and had profound social, ecological, and economic implications for communities beyond the decision makers. The cases span a variety of cultures, countries, and combinations of social actors. They were selected to show a variety of positions in favor of or against the primary controversial action. Collectively, these cases begin to capture the diverse dimensions and complexity of current global energy transitions. These transitions often involve multiple decisions with unique nuances. At the broadest level, it remains uncertain which fuel(s) will be "best," both practically (in terms of technology and economics) and ethically. There is no consensus on the best single energy resource or technology. For instance, we continue to combust oil and produce avoidable emissions, while its other uses are largely emission-free, such as lubrication, hydraulics, and making other materials such as polyesters and plastics (which are also controversial in terms of waste management and extraction). Solar energy is a model renewable source, but producing photovoltaic panels involves mining and the use of potentially toxic chemicals which are difficult to recycle. Natural gas is cleaner than other fossil fuels but still creates significant emissions. Nuclear energy generation does not emit carbon but threatens radioactivity events with a high human cost and involves difficult waste management. Hydropower has been a staple renewable energy useful as a baseline power supply, but it displaces populations of humans or non-humans. Beyond these more noticeable concerns, there is a plethora of other ethical worries for each of the selected cases, in terms of their intertwined human, cultural, and ecological dimensions. Without a standardized method for conducting ethical evaluations, these controversies will endure. The primary motivation for proposing our framework and constructing ethical arguments is to transparently establish the reasoning that justifies (or condemns) an action.

With the ethical principles and details of our cases established, we can apply our framework to the cases in Table 3, below. For the sake of simplicity and exposition, we ignore the option of applying multiple principles to individual cases, simultaneously. Instead, we limit our analysis to a single ethical principle for each case.

Each example in Table 3 consists of three components: (1) details of the case, including the relevant decisions (or actions) under consideration; (2) the principles and terminology of the ethical theory being applied; and (3) a verdict in favor of (or in opposition to) the targeted action. ${ }^{3}$ Our framework and modeled case analyses are intended to serve as a template for others, especially energy decision makers and researchers in the field, to conduct their own ethical analyses of geographically and culturally diverse energy decisions. Moreover, we hope that our framework can serve to organize and systematize the literature on energy ethics to establish a new research agenda that involves new applications (i.e., other controversial energy decisions) of our framework.

Although we evaluate each case from the perspective of one ethical principle, a more thorough analysis would evaluate each case with multiple principles in the framework since any principle can create an ethical objection and thereby require some response to maintain ethical integrity. For practical purposes, it seems reasonable to suppose that a targeted decision or action judged to be ethical by multiple principles simultaneously will provide stronger evidence for believing that the decision or action is ethical compared to an action that is only judged to be ethical when applying a single principle.

\section{Discussion}

A growing chorus of energy researchers has called for infusing ethics into "real-world" energy decisions. Because the energy sector is a major source of the greenhouse gases that bring about rising temperatures, we should encourage energy researchers to scrutinize the ethical merit of many energy decisions, such as the paradigmatic cases we evaluated. Overall, we believe that taking energy ethics for granted during the Anthropocene would be a grave mistake.

While other scholars have proposed disparate methods of applying ethics to energy decisions, there is still no agreement on the best way to proceed. Scholars using the term "energy ethics" do not always integrate well-

\footnotetext{
${ }^{3}$ To be clear, decision makers who employ this framework for evaluating the ethical merit of energy decisions make value judgements. Whether implicit or explicit, one should expect that a policy maker's personal values, interests, and beliefs will influence their ethical analysis [8].
} 
Table 3 Five example applications ${ }^{a}$

Application 1: Lakota ethics applied to construction of the Dakota Access Pipeline (pipeline construction + Lakota ethics + opposition to action)

We can use Lakota ethics to argue against the pipeline's construction. Hoarding profits rather than distributing them to the community conflicts with the virtue of generosity. The pipeline helps perpetuate our addiction to oil, thereby creating a never-ending loop of social harm. Furthermore, the lack of safety precautions regarding potential spills shows a reckless character not mindful of others as relatives. The threats to animals other than humans are even greater, since humans can clean up spills and more consciously avoid the area in the case of an accident. Lakotas argue that their land is sacred, and pipeline construction is a violation of their respect for the hallowed land. The need for safe drinking water sources and mitigation of climate change threats remain unmet needs within the community. These reasons employ Lakota ethics to condemn the pipeline's construction and resist the continued development of a fossil fuel that produces substantial costs to global climate stability.

\section{Application 2: Navajo ethics applied to Navajo Nation's transition to solar (pursuit of solar + Navajo ethics + in favor of action)}

Navajo ethics can be used to argue in favor of the transition to solar. The decision to pursue solar ought not to be excessive or use others for one's gain. Therefore, producing more energy than is necessary to meet demand locally (due to insufficient transmission access, for instance) might be an example of excess to avoid. This consideration becomes particularly salient as the Navajo are currently welcoming solar installations, albeit cautiously, taking care to avoid possible bankruptcy or to overburden the electric utilities with too much new generation. Similarly, the Navajo Tribal Utility Authority (NTUA) has confirmed a general willingness of members of the Nation who live near potential solar project sites a willingness to give up their grazing rights in that location to release the land for construction [24]. By communicating with these families directly, the NTUA is showing respect and therefore regaining the trust of Navajos.

To the Navajo Nation, solar energy development will help reconcile some of the previous wrongs they suffered by agreeing decades ago to allow coal mining and power plant operation on tribal land. If remediation of the power plant site and the mined land are completed fully and responsibly in the future, these measures would further support reconciliation. Further to the point of reconciliation, tribal willingness to support solar energy development would be in compliance with a strong Navajo policy to reduce conditions of poverty that continue to plague the Nation. Taking this position further, ethical considerations could also help influence the choice of photovoltaic models, if these were chosen because they are created with less toxic substances and production wastes. Mindfulness of waste would demonstrate ethical concerns not just locally but the entire life cycle of the modules themselves [25]. In these ways, Navajo ethics would support the transition to solar energy.

Application 3: Virtue theory applied to fracking in Washington County, PA (fracking + virtue ethics + opposition to action)

The Aristotelian notion of the Golden Mean [26] can be applied to fracking. While the abundance and relatively low carbon content of natural gas are enticing, rushing too rapidly into fracking could be excessively greedy or deficiently mindful of risks. Extracting gas so that the wells dry too quickly could lead to a "bust" market and the disappearance of revenue. A reckless proliferation of wells can manifest negligence for the environment and impair human health. The pursuit of maximum profit could lead to unsafe drilling, contamination of water supplies, and excessive methane leaks.

(Fracking + virtue ethics + in favor of action)

However, a supporter of fracking might describe it as a moderate action and might argue that a moratorium on fracking is a deficient action since fracking done with some reasonable amount of care can be relatively safe. Stakeholders may take various views as they judge whether fracking can be performed in a manner that is responsible to all parties.

\section{Application 4: Deontological theory applied to uranium mining in Virginia (mining + deontology + opposition to action)}

Kant's ethics can be applied to the uranium dispute. Regarding intentions, the public alarm produced by the Three Mile Island nuclear plant accident near Harrisburg, PA, in 1979 influenced the 1982 moratorium on uranium mining in Virginia. However, the lawsuit by Virginia Uranium Inc. and other owners alleges that the ban intentionally seizes authority over nuclear waste, which is a federal responsibility [27]. The mining company also argues that the ban is self-defeating since it contests the government's goal of "an adequate supply of nuclear fuel for power plants and national defense." In opposition to the lawsuit, the state government and judges might rule that allowing mining as an economic boon to the community could be self-defeating since it is feared to drive potential students from local boarding schools, detract companies from entering the city, present an unsightly mine, and threaten the safety, health, and welfare of the community. The fear is that the company might be putting others in the community at risk for its financial gain. In response, the company pushes for autonomy. On June 17th, 2019, the Supreme Court upheld Virginia's ban on uranium mining, thus ending Virginia Uranium et al. v. Warren et al., No. 16-1275.

Regardless, the difference of opinions also relates to the implied disrespect of future generations regarding nuclear waste products. At present, no one-anywhere on the planet-has devised a system to safely isolate such long-lived wastes from biological organisms for thousands of years. At the same time, because nuclear-generated electricity produces few emissions compared to other energy conversion processes, some argue that it is one solution to concerns about climate change. According to a Kantian perspective, the impossibility of the company to show a universalizable method for responsibly containing wastes is in line with the decision of the Supreme Court to uphold the ban.

Application 5: Consequentialism applied to construction of the Xiaolangdi Dam (dam construction + consequentialism + opposition to action)

Consequentialism can be applied to the construction of the Xiaolangdi Dam. The dam has disrupted the natural wet-dry cycle of the wetlands, which has destroyed the ecological services of the riparian ecosystem, such as fertility on the floodplain that is no longer resupplied naturally by the river. This degradation results in a need for more fertilizers on the farmland located there and a greater concern for the effect of such artificial fertilizers on the quality of any runoff [28]. Flooding of traditional villages has caused social problems. For example, resettlement impairs production capacity, social unity, material well-being, cultural access, and physical, psychological, and emotional health [29, 30]. Involuntary resettlement has been associated with increased socio-cultural stress, crime, morbidity, and mortality [31]. Displaced villagers are frequently (re)located in "remote and inhospitable, resource-scarce mountain regions," where they struggle with food insecurity and impoverishment as they are no longer able to live off of the land [29]. For example, resettled farmers from Baigou were given irrigated land, but it was smaller than the land they had previously owned. Of these farmers, $11 \%$ harvested less; $63 \%$ of them lost income, and there were employment collapses after construction ended that left many people jobless. Coal mining and other activities were impacted, particularly by a rise in landslides due to the raised water level in the reservoir, which affected the stability of adjacent slopes [32]. While some residents have transitioned to fishing and tourism of the new reservoir, the fish are now smaller and less diverse.

We can weigh these negative consequences against the benefit of flood control. Historic floods had been so bad they changed the course of the river, killed people, and wiped out irrigated land. Tourism at the dams, plus the use of irrigation, attracts $\$ 200$ billion in annual investment, and drinking water, electricity, and phone access have improved, while food production rises [33]. 
Table 3 Five example applications ${ }^{\mathrm{a}}$ (Continued)

As an alternative to involuntary or weakly-incentivized resettlement, researchers now stress that the relocated people are allowed to participate in the decision-making process they will have more control of their future, which may better enhance their capabilities in the development-forced displacement and resettlement process [34]. In this case, consequentialism would lead to two different prescriptions depending on the scale considered. Considered in such a broader context, it would be in favor of the dam construction because the benefits affect a majority of the population and thus cohere with the principle of maximization of wealth for the majority of the people involved. However, if consequentialism is applied in a narrower sense, only considering the outcomes for the local stakeholders, then it would prescribe to not build the dam.

${ }^{a}$ The highlighted words in this table identify the ethical principle selected and applied to each case

established ethical principles into their research, making their adoption of the term problematic and perhaps misleading. Although we do not expect our approach to instantly forge a consensus, our objective has been to advance the field of energy ethics. We have proposed to conceive of energy ethics as applied ethics, rather than as energy justice, descriptive ethics, or metaethics, as found in the literature. An applied ethics framework can serve to scrutinize future energy decisions with various ethical principles and prioritize the perspectives of those most affected by the decision. This short communication simply provided a sample of this approach, which we hope will galvanize the conversations on energy ethics as applied ethics, which could eventually burgeon into a thriving interdisciplinary field of research.

\section{Conclusion}

Energy ethics as applied ethics highlights ethical problems that deserve the attention of energy decision makers. Our framework allows crude but effective ethical prescriptions in concrete cases that may be culturally sensitive. Moreover, our framework offers a shared language and rules so that more attention can be directed to the decision at hand. Promoting an operational, solutions-oriented approach to ethical analysis entails going beyond merely identifying problematic situations to proposing solutions. With energy ethics as applied ethics, decision makers possess a conceptual tool to analyze contentious energy projects. Although there may be no decisive way to determine which ethical principle or set of principles that practitioners should select for evaluating energy decisions and actions, a general two-step recommendation might consist of the following:

1. The local ethical perspective should be prioritized and used as the first evaluative lens.

2. The practitioner or decision maker must judge the ethically relevant aspects of the decision at hand and choose the most plausible ethical principle(s) to employ.

\section{Acknowledgements}

We are grateful for the constructive feedback provided by two anonymous reviewers and an editor of this journal.

\section{Authors' contributions}

$J B$ designed the research and conducted primary data analysis for the case studies. GF, SB, CTD, and MP collaborated with JB to develop the framework. All authors edited and approved the final manuscript.

\section{Funding}

CTD received funding support from ASU LightWorks for this research.

\section{Availability of data and materials}

Not applicable.

Ethics approval and consent to participate

Not applicable.

\section{Consent for publication}

Not applicable.

\section{Competing interests}

The authors declare that they have no competing interests.

\section{Author details}

${ }^{1}$ California University of Pennsylvania, California, PA, USA. ${ }^{2}$ Philosophy of Engineering, Technology Assessment \& Science Research Group, Institute for Technology Assessment and Systems Analysis, Karlsruhe Institute of Technology, Karlsruhe, Germany. ${ }^{3}$ School of Sustainability, Arizona State University, Tempe, AZ, USA. ${ }^{4}$ School of Historical, Philosophical and Religious Studies, Arizona State University, Tempe, AZ, USA. ${ }^{5}$ Center for the Study of Economic Liberty, Arizona State University, Tempe, AZ, USA. ${ }^{6}$ School of Geographical Sciences and Urban Planning, Arizona State University, Tempe, AZ, USA.

Received: 17 February 2020 Accepted: 21 July 2020

Published online: 13 August 2020

\section{References}

1. CAIT Climate Data Explorer. https://www.wri.org/blog/2017/04/interactivechart-explains-worlds-top-10-emitters-and-how-theyve-changed. Accessed 1 Mar 2019

2. Sherwood SC, Huber M (2010) An adaptability limit to climate change due to heat stress. P Natl Acad Sci USA 107(21):9552-9555. https://doi.org/10. 1073/pnas.0913352107

3. Miller CA (2014) The ethics of energy transition. Proceedings of the IEEE Symposium on Ethics in Engineering, Science, and Technology. IEEE Symposium on Ethics in Engineering, Science, and Technology. Chicago, IL. https://doi.org/10.1109/ETHICS.2014.6893445

4. Sovacool BK (2014) Diversity: energy studies need social science. Nat 511(7511):529. https://doi.org/10.1038/511529a

5. Probert SD (1976) Energy engineering: ethics of an emerging profession. Appl Energy 2(3):217-223. https://doi.org/10.1016/0306-2619(76)90026-X

6. Sovacool BK, Heffron RJ, McCauley D, Goldthau A (2016) Energy decisions reframed as justice and ethical concerns. Nat Energy 1(5):1-6. https://doi. org/10.1038/nenergy.2016.24

7. Miller D (2017) Justice. The Stanford Encyclopedia of Philosophy. https:// plato.stanford.edu/archives/fall2017/entries/justice/

8. Frigo G (2018) The energy ethic and strong sustainability: outlining key principles for a moral compass. In: Bonnedahl K, Heikkurinen P, (eds) Strongly sustainable societies. Routledge.

9. Aristotle (1984) Nicomachean ethics. In: Barnes J (ed) The complete works of Aristotle. Princeton University Press, Princeton, NJ

10. Kant I (1964) Groundwork of the metaphysics of morals (1785). Paton, HJ (trans). Harper and Row, New York. 
11. Bentham J (2005) Introduction to the principles of morals and legislation (1789). In: Bowring J (ed) The works of Jeremy Bentham. Adamant Media Corporation, Chestnut Hill, MA

12. Mill JS (1991) Utilitarianism. In: Robson JM (ed) Collected works of John Stuart Mill. University of Toronto Press, Toronto

13. Byerly R (2015) Sitting in the hoop of the people: linking Lakota values and business ethics. J Relig Bus Ethics 3(1):1-18

14. Caldwell C (2017) Lakota virtues and leadership principles: insights and applications for ethical leaders. J Manag Dev 36(3):309-318. https://doi.org/ 10.1108/JMD-03-2016-0038

15. Craig RH (1999) Institutionalized relationality: a Native American perspective on law, justice and community (kinship relations, collective rights, and mutual responsibilities within Lakota and Dakota tribal society). Annu Soc Christ Ethics 19:285-309

16. Verbos AK, Gladstone JS, Kennedy DM (2011) Native American values and management education: envisioning an inclusive virtuous circle. J Manag Educ 35(1):10-26

17. Vecsey C (2015) Navajo morals and myths, ethics and ethicists. J Relig Ethics 43(1):78-121

18. Yazzie R (1994) Life comes from it: Navajo justice concepts. N. M. Law Rev 24:175-190

19. NYC stands with Standing Rock collective. (2016) \#StandingRockSyllabus. https://nycstandswithstandingrock.wordpress.com/standingrocksyllabus/.

20. Randazzo R (2017, February 13) Utilities vote to close Navajo coal plant at end of 2019. The Arizona Republic. http://www.azcentral.com/story/money/ business/energy/2017/02/13/utilities-vote-close-navajo-generatingstationcoal-plant-2019/97866668/

21. Mall A (2014, February 28) Incidents where hydraulic fracturing is a suspected cause of drinking water contamination. Natural Resources Defense Council. www.nrdc.org

22. Schneider GS, Barnes R (2018, November 4) Supreme Court to consider Virginia uranium case that divides a rural county. The Washington Post: Virginia Politics. https://www.washingtonpost.com/local/virginia-politics/ supreme-court-to-consider-virginia-uranium-case-that-divides-a-ruralcounty/2018/11/03/2a4e06f8-dea6-11e8-85df-7a6b4d25cfbb_story. html?noredirect=on\&utm term $=.2125 c 4 a 56 f 40$

23. Verdict Media (2019) Xiaolangdi hydroelectric power plant. https://www power-technology.com/projects/xiaolangdi/

24. Hay M (2018) A new solar facility creates jobs and greater energy independence for the Navajo Nation. Make Change, Aspiration Partners, Inc https://www.makechange.aspiration.com/articles/new-solar-facility-createsjobs-and-greater-energy-independence-for-navajo-nation

25. Powell DE (2015) The rainbow is our sovereignty: rethinking the politics of energy on the Navajo Nation. J Political Ecol 22:53-78. https://doi.org/10. 2458/v22i1.21078

26. Kraut R (2018) Aristotle's ethics. The Stanford Encyclopedia of Philosophy, Zalta EN (ed). https://plato.stanford.edu/archives/sum2018/entries/aristotleethics/

27. Schneider GS, Barnes R (2018, November 4) Supreme Court to consider Virginia uranium case that divides a rural county. The Washington Post: Virginia Politics. https://www.washingtonpost.com/local/virginia-politics/ supreme-court-to-consider-virginia-uranium-case-that-divides-a-ruralcounty/2018/11/03/2a4e06f8-dea6-11e8-85df-7a6b4d25cfbb_story. html?noredirect=on

28. Zhao T, Richards K, Xu H, Meng H (2012) Interactions between damregulated river flow and riparian groundwater: a case study from the Yellow River, China. Hydrol Process 26(10):1552-1560. https://doi.org/10.1002/hyp. 8260

29. Webber M, McDonald B (2004) Involuntary resettlement, production and income: evidence from Xiaolangdi, PRC. World Dev 32(4), 673-690. https:// doi.org/10.1016/j.worlddev.2003.10.010

30. Wu Z, Wu Z, Penning M, Zeng W, Li S, Chappell N (2016) Relocation and social support among older adults in rural china. J Gerontol Ser B Psychol Sci Soc Sci 71(6):1108-1119. https://doi.org/10.1093/geronb/gbu187

31. Abuodha JOZ (2002) Environmental impact assessment of the proposed titanium mining project in Kwale District, Kenya. Mar Georesour Geotechnol 20:199-207. https://doi.org/10.1080/03608860290051895

32. Kong D, Miao C, Wu J, Borthwick A, Duan G, Zhang Q (2017) Environmental impact assessments of the Xiaolangdi Reservoir on the most hyperconcentrated laden river, Yellow River, China. Environ Sci Pollut Res 24(5):4337-4351. https://doi.org/10.1007/s11356-016-7975-4
33. Hong P, Singh S, Ramic J (2009) Development-induced impoverishment among involuntarily displaced populations. J Comp Soc Welf 25(3):221-238. https://doi.org/10.1080/17486830903189972

34. Wilmsen B, Webber M (2015) What can we learn from the practice of development-forced displacement and resettlement for organised resettlements in response to climate change? Geoforum 58:76-85. https:// doi.org/10.1016/j.geoforum.2014.10.016

\section{Publisher's Note}

Springer Nature remains neutral with regard to jurisdictional claims in published maps and institutional affiliations.
Ready to submit your research? Choose BMC and benefit from:

- fast, convenient online submission

- thorough peer review by experienced researchers in your field

- rapid publication on acceptance

- support for research data, including large and complex data types

- gold Open Access which fosters wider collaboration and increased citations

- maximum visibility for your research: over $100 \mathrm{M}$ website views per year

At $\mathrm{BMC}$, research is always in progress.

Learn more biomedcentral.com/submissions 